Бұл CC BY-NC-ND лицензиясы бойынша қол жетімді мақала (https://creativecommons.org/licenses/by-nc-nd/3.0/) «Ғылымның өзекті мәселелері» - Халықаралық практикалық интернет- конференция материалдары

Басылым II, Қараша 2019

ISBN 978-601-323-144-0

https://doi.org/10.31643/2019.009

\author{
Есбенбетова Жанат Халыковна \\ «Қазақстан Республикасы Еңбекті және \\ халықты әлеуметтік қорғау министрлігінің \\ Еңбекті қорғау жөніндегі республикалық \\ ғылыми-зерттеу институты» ШЖҚ РМК \\ Кәсіби тәуекелдерді басқару зертханасының басшысы \\ Жаратылыстану ғылымдарының магистрі \\ Нұр-Сұлтан қ., Қазақстан \\ E-mail: nauka@rniiot.kz ORCID ID: 0000-0002-3966-327X
}

\title{
Керамикалық кірпіш өндіруші кәсіпорындағы еңбекті қорғауды басқару жүйесін талдау
}

\begin{abstract}
Абстракт: Қазақстан Республикасында Халықаралық еңбек ұйымының №187 Конвенциясының ратификациялануына байланысты, еңбекті қорғауды басқарудың жүйесін жетілдіру мақсатында кең ауқымдағы ғылыми-зерттеу жұмыстары жүргізіліп жатыр. Мақалада үш кезеңге бөлінген ғылыми-техникалық бағдарлама аясында керамикалық кірпіш өндіруші кәсіпорындағы жүргізілген ғылыми-зерттеу жұмыстарының бірінші және екінші кезеңдегі нәтижелері қарастырылған. Зерттеу нәтижелері бойынша кәсіпорындағы қолданыстағы еңбекті қорғауды басқару жүйесіне талдау жасалды. Кәсіпорындағы мамандықтардың кәсіби тәуекелдері бес көрсеткіш бойынша бағалаланды. Нәтижесінде кәсіпорында кәсіби тәуекелдерді есепке ала отырып, еңбекті қорғауды басқарудың біріктірілген жүйесі бойынша құжаттар пакеті дайындалып, апробациядан өтті. Апробация кезінде Қазақстан Республикасы Еңбекті және халықты әлеуметтік қорғау министрлігінің Еңбекті қорғау бойынша Республикалық ғылыми-зерттеу институтының қызметкерлерімен кәсіпорында қауіпсіздік және еңбекті қорғау бойынша жауапты мамандардың біргелікте әзірлеген құжаттары бойынша семинарлар жүргізіліп, сертификаттар тапсырылды.
\end{abstract}

Тірек сөздер: еңбекті қорғауды басқару жүйесі, кәсіби тәуекел, ғылыми-зерттеу жұмысы, пилоттық кәсіпорын, еңбек жағдайлары

\section{Kipicпе}

Қазақстан Республикасында еңбекті қорғау саласындағы ғылыми әзірлемелер кәсіпорындардағы еңбекті қорғауды жақсартуға бағытталған, жаңа еңбек кодексі қабылданды, тиісті нормативтік-құқықтық база жаңартылып жатыр [1-2]. Еңбек кодексінің 182 бабына сәйкес жұмыс берушілер еңбек жағдайларын жақсартуға міндетті, бірақ еңбек заңнамасында, өндірісте, еңбек жағдайларды жақсартудың нақты шаралары жазылмаған. Осы сәтте еңбекті қорғау (әрі қарай - ЕК) бойынша құжаттамаға ең төмен талаптарды айқындай отырып, еңбекті қорғауды басқарудың ұлттық жүйесін ұйымдастыруға бірыңғай тәсілдемелерді Халықаралық стандарттарға сай, соның ішінде кәсіби тәуекелдерді басқара (әрі қарай-КТБ) отырып, әзірлеу және барлық зерттеулерді жүйелеу қазіргі кездегі өзекті талаптар болып саналады [3-5]. Сол себепті «Қазақстан Республикасы Еңбек және халықты әлеуметтік қорғау министрлігінің Еңбекті қорғау жөніндегі республикалық ғылымизерттеу институты» ШЖҚ РМК (бұдан әрі - «ҚР ЕХӘҚМ РҒЗИ» ШЖҚ РМК) ғылыми-техникалық бағдарлама шеңберінде «Қазақстан Республикасы экономикасының басым секторларында қауіпсіз еңбекті қамтамасыз етудің ғылыми-әдістемелік негіздерін әзірлеу» бойынша ғылыми-зерттеу жұмыстарын жүргізуде [6]. 


\section{Зерттеу әдісі}

Зерттеу жұмыстары 4 кезеңнен тұрады:

$>$ Еңбекті қорғауды басқарудың халықаралық стандарттарына және инновациялық үрдістеріне сәйкестігі мәніне Қазақстанда ЕҚ саласындағы реттеуді салыстырмалы талдау (2018ж.);

$>$ ҚР кәсіпорындардағы еңбекті қорғауды басқару жүйесі (әрі қарай - ЕҚБЖ) қолданыстағы жай-күйін бағалау (2019 ж.);

$>$ ҚР кәсіпорындардағы КТБ негізінде біріктіріліген ЕҚБЖ енгізу (2019 ж.);

> ҚР экономикасының басымды секторларындағы КТБ негізінде біріктірілген ЕҚБЖ тиімділігін бағалау және т.б. (2020 ж.).

Зерттеу жұмысының екінші кезеңінде ҚР кәсіпорындардағы қолданыстағы ЕҚБЖ жай-күйін бағалау мақсатында 20 пилоттық кәсіпорын таңдалып алынды. Соның бірі өңдеу саласына тиесілі керамикалық кірпіш өндіру кәсіпорыны. Керамикалық кірпішті өндіруді ұйымдастырудың маңызды қағидаларының бірі өндіріс процесінің барлық кезеңдерінде қауіпсіз және зиянсыз еңбек жағдайларын жасау болып табылады және олар қауіпсіздік талаптарына сай болуы керек. Кәсіпорынның қолданыстағы ЕҚБЖ еңбек қауіпсіздігі және еңбекті қорғау саласындағы заңнама талаптарының сақталуын ескере отырып, төмендегі көрсеткіштер бойынша бағаланды:

- еңбекті қорғау саласындағы міндеттерді лауазымды адамдар арасында бекіту;

- еңбек қауіпсіздігі және еңбекті қорғау мәселелері бойынша кәсіпорын қызметкерлері мен басшыларын оқыту, нұсқау беру және білімін тексеру жүргізу;

- жұмыскерлерді жеке қорғану құралдарымен (бұдан әрі-ЖҚҚ) қамтамасыз етілуі);

- еңбекті қорғау талаптарының сақталуына ішкі бақылауды жүзеге асыру;

- еңбек қауіпсіздігі және еңбекті қорғау жөніндегі іс-шаралар жоспарының болуы;

- өндірістік объектілерді еңбек жағдайлары бойынша аттестаттаудан өткізу (әрі қарайаттестаттау).

Сонымен қатар, кәсіпорында Халықаралық талаптарға сәйкес, еңбекті қорғауды басқару жүйесін кәсіби тәуекелді басқаруды енгізе отырып жасау мақсатында, Институт тарапынан кәсіпорында кәсіби тәуекелдерді басқару жүйесін енгізу бойынша әдістемелік ұсынымдар негізінде [7], онда әр мамандық бойынша тәуекел дәрежесін жеке бағалау жүргізілді. Тәуекел дәрежелері 5-ке бөлінеді: рұқсат етілген, төменгі, орташа, жоғары және өте жоғары.

Зерттеу нәтижелері көрсеткендей, кәсіпорында 250 ден астам жұмыскер бар. Еңбекті қорғау саласын ұйымдастыру жұмыстары Еңбекті қорғау және техника қауіпсіздігі бойынша инженерге жүктелген. Еңбек қауіпсіздігі және еңбекті қорғау мәселелері бойынша кәсіпорын жұмыскерлері мен басшыларын оқыту, нұсқау беру және білімін тексеру жүргізу жұмыстары еңбек заңнамаларына сәйкес жүргізілген. Жұмыскерлер ЖҚҚ-ымен қамтамасыз етілген. Еңбекті қорғау талаптарының сақталуын жүзеге асыру мақсатында ішкі бақылау жұмыстары жүргізілген. Еңбек қауіпсіздігі және еңбекті қорғау жөніндегі іс-шаралардың жылдық жоспарлары жасалған. Өндірістік объектілерді еңбек жағдайлары бойынша аттестаттау жұмыстары 2018-2019 жылдары кезеңмен өткізілген. Кәсіби тәуекелдерді бағалау жұмыстары жоғарыда аталған әдістемелік ұсынымдар негізінде жүргізілді. Кәсіпорындағы әр мамандық бойынша зиянды және қауіпті факторларды анықтау (идентификациялау) жүргізілді. Әрі қарай, бес көрсеткіш негізінде, өндірістік орта факторларының зияндылық дәрежесі, еңбек процесінің жарақат алу қаупі, өндірістік жабдықтардың қауіпсіздігі, ЖҚҚ қамтамасыз етуі және жұмыскерлердің сырқаттануына еңбек жағдайларының әсерін талдау арқылы есептелді. Кәсіби тәуекел 114 мамандық бойынша бағаланды.

Кәсіби тәуекелді бағалау нәтижелері бойынша (сурет), еңбек жавдайларының зияндыльвы кәсіпорында жүргізілген аттестаттау қорытындылары негізінде, зиянды өндірістік факторларға көбірек ұшырайтын мамандықтарды, олардың түрлерін анықтау және жұмыскерлердің ағзасына әсер ету дәрежесін анықтау үшін жүргізілді.

Белгілі болғандай, негізінен кеңсе қызметкерлерінің (хатшы-референт, бас бухгалтер, техникалық сапаны бақылау, сату жөніндегі бөлімдердің жұмыскерлері, инженер-бағдарламашы және т.б.) жұмыс орындары 2 дәрежелі тәуекел (төменгі) деп бағаланды, яғни олардың жұмыс орындарындағы компьютерлерден болған электромагнит өрістерінің рұқсат етілген шекті (3.1 зияндылық класы) шамасынан артық болған. Ал автокөлік цехының жұмыскерлері (жүк көлігінің 
жүргізушілері, машинисттер, жанар-жағар май тасушы көліктердің жүргізушілері, краншылар және т.б.) 3 дәрежелі тәуекел (орташа) деп бағаланған, себебі аталған мамандықтардың жұмыс орындарында химиялық зиянды факторлардың концентрациясы руқсат етілген шекті шамандан артық болған (3.1 зияндылық класы), сонымен қатар еңбек процесінің қауырттылығы мен ауырлығы да бағалауда 3.1 зияндылық класы белгіленді.

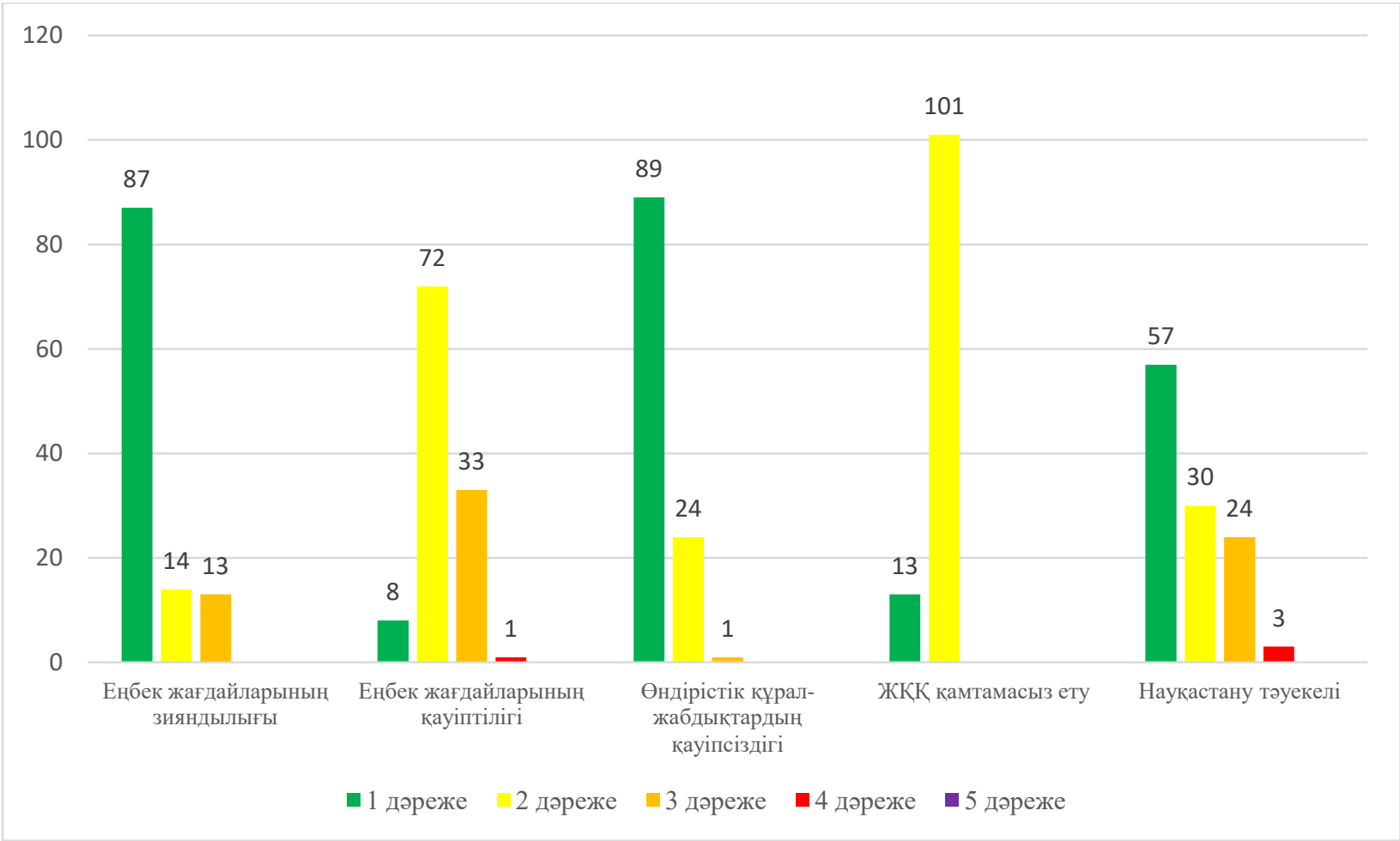

Еңбек жсаддайларының қауіптілігі көрсеткіші механикалық факторлар көбірек әсер ететін мамандықтарды анықтау үшін жүргізіліп, олардың түрлері мен жұмыскерлерге ықпал ету дәрежесі анықталды. Бағалау еңбек процесінің мазмұнын, функционалдық міндеттерін, орындалатын жұмыс түрлерін анықтайтын нормативтік құжаттардың талаптарына сәйкес жүргізілді. Зерттеу нәтижесі бойынша өндірістік бөлімдердің 33 мамандығының жұмыс орны 3 дәрежелі тәуекел деп бағаланды. Себебі, ол мамандықтардың жұмыс барысында негізінен, өндірістік құралдар, механизмдер, машиналардың қозғалатын, айналатын бөліктерінің әсер етуі (соққы, қапсырылу, қысылып қалу) себеп болып отыр.

Өндірістік ж⿻абдықтардың қауіпсіздігін бавалау, өндірістік жабдықтың қауіпті әсер ету аймағында болатын мамандықтарды анықтау мақсатында өндірістік және қосалқы бөлімдерде жүргізілді, Жұмыс орындарындағы өндірістік жабдықтардың қауіпсіздігіне қойылатын барлық талаптар (техникалық, пайдалану, құжаттама) сақталған. Өндірістік жабдықтардың қауіпсіздігін бағалау нәтижелері бойынша, зерттелген 26 мамандықтың барлығы тәуекелдің 2-дәрежесіне жататындығы анықталды, себебі кәсіпорындағы өндірістік технология замануи талаптарға сай, яғни жаңартылған өндірістік жабдықтар қолданылады.

Жеке қорганыс құралдарымен (ЖҚК) қамтамасыз етілуін бағалау арнайы киіммен, аяқ киіммен және т.б. қамтамасыз етілмеген мамандықтырды анықтау. 3 талап бойынша белгіленген талаптарға сәйкес үшін жүргізілді, оларға: ЖҚҚ берудің белгіленген стандарттарға сәйкестігі; ЖҚҚ беру үшін нормативтік-техникалық құжаттаманың болуы; пайдаланылған ЖҚҚ сапа сертификаттарының болуы.Бағалау нәтижелері бойынша кәсіпорынның барлық мамандықтары үшін 2-ші дәрежелі тәуекел анықталды, өйткені өндіріс процесінде қолданылатын жеке қорғаныс құралдары сертификатталған, сонымен қатар нормативтік-техникалық талаптарға сай келеді.

Науқастану тәуекелі науқастануға аса бейім мамандықтарды анықтау үшін бағаланды. Ол үшін кәсірорындағы тіркелген еңбекке жарамсыздық парақтары талданды және күндерінің ұзақтығын белгілеу арқылы, науқастардың даму қаупі дәрежесі анықталды. Зерттеу нәтижесі бойынша, екі жыл ішінде 35 мамандық бойынша жұмыскерлердің еңбекке жарамсыздық парағы тіркелген. 


\section{Қорытынды}

Бағалау қорытындысы бойынша, көп науқастанатын мамандықтар негізінен, әкімшілік басқару бөлімшелердегі мамандықтармен қатар, негізгі бөлімше мамандықтары да жиі екені анықталды. Бұл өз кезегінде, кәсіпорында жұмыскерлердің денсаулығын жақсартуға бағытталған басқа да іс-шараларды жоспарлау керек екендігі ұсынылады.

Жоғарыда көрсетілген міндеттерді орындау барысында алынған нәтижелер негізінде, кәсіпорында еңбекті қорғауды басқарудың біріктірілген жүйесін енгізу үшін құжаттаттар пакеті дайындалды, оларға:

- кәсіпорындағы еңбекті қорғау саясаты;

- кәсіби тәуекелдерді бағалау бойынша нұсқаулық;

- өндірістік объектілерді еңбек жағдайлары бойынша аттесттаттау тәртібі;

- жұмысшыларды арнайы киіммен, арнайы аяқ киіммен және жеке қорғаныс құралдарымен қамтамасыз ету туралы ереже;

- еңбек қауіпсіздігі және еңбекті қорғау бойынша оқыту (қайта даярлау), нұсқаулық беру және білімін тексері тәртібі туралы ереже;

- міндетті медициналық тексерулерді ұйымдастыру туралы ереже;

- жұмысқа байланысты жазатайым оқиғалар туралы хабарлау және тергеу тәртібі.

Әрі қарай, жаңа жүйені енгізу бойынша қажетті құжаттардың толық пакетін апробациялау мақсатында, семинар өткізілді және оларды сол кәсіпорындарға сәйкестендіру мақсатында түзетулер жасалды. Келесі кезеңде, Ғылыми-техникалық бағдарламаның апробациялаудан өткізіп жатқан жүйенің экономикалық тиімділігін анықтау жоспарлануда. Осылайша, ғалымдардың, жұмыс берушілердің, еңбекті қорғау қызметі мамандарының, жеке кәсіпкерлердің еңбекті қорғауды басқарудың жаңа жүйесін апробациядан өткізу кезіндегі ынтымақтастығының нәтижесі еңбекті қорғауды басқару біріктірілген жүйесінің түпкілікті нұсқасы болашақта Қазақстан Республикасының барлық кәсіпорындарында енгізілу үшін әзірленетін болады.

\section{Yesbenbetova Zhanat Halykovna}

Master of Science, Ecology,

Head of the laboratory for the study of occupational risks,

RSE on the right of economic management

«Republican Research Institute for Labor Protection,

Ministry of Labor and Social Protection of the Population

of the Republic of Kazakhstan», Nur-Sultan, Kazakhstan.

E-mail: nauka@ rniiot.kz ORCID ID: 0000-0002-3966-327X

\section{Analysis of the labor protection management system at the ceramic brick production enterprise}

\footnotetext{
Abstract: Due to the ratification of Convention No. 187 of the International Labor Organization, a large-scale research project is being carried out in the Republic of Kazakhstan to improve labor protection management system. The article presents the results of the first and second stages of research carried out at the enterprise for the production of ceramic bricks in the framework of the scientific and technical program, which is divided into three stages. The existing labor protection management system at the enterprise was analyzed based on the results of the study. At enterprises, professional risks were assessed by five indicators. As a result, in company was developed and tested a package of documents on an integrated labor safety management system taking into account professional risks. During the approbation, the staff of the Republican Research Institute for labor protection of the Ministry of labor and social protection of the population of the Republic of Kazakhstan held seminars on jointly developed documents of responsible specialists in safety and labor protection at the enterprise and awarded certificates.

Keywords: occupational safety management system, professional risk, research work, pilot enterprise, working conditions.
} 
Мақалаға сілтеме: Есбенбетова Ж. Х. (2019) Керамикалық кірпіш өндіруші кәсіпорындағы еңбекті қорғауды басқару жүйесін талдау. «Ғылымның өзекті мәселелері» - Халықаралық практикалық интернет- конференция материалдары / Materials of International Practical Internet Conference "Challenges of Science". ISBN 978-601-323-144-0. Басылым II, 2019. Бет: 55-59. https://doi.org/10.31643/2019.009

\section{Пайдаланылған әдебиеттер тізімі}

[1] Қазақстан Республикасының Еңбек кодексі 2015 жылғы 23 қарашадағы http://adilet.zan.kz/kaz/docs/K1500000414.3

[2] Под руковоством Бисакава С.Г. Постатейный практический комментарий//Алматы: ТОО «МЦФЭР-Казахстан», 20167-1096 с.-на казахском и русском языках.

[3] Москвичев А., Симонова Н., Вихров С., Иванов В. Совершенствование системы управления охраной труда на основе концепции управления профессиональными рисками // Охрана труда и социальное страхование. 2015 , № 9.

[4] Кашинцева Л., Хадарцев А., Хрупачев А. Производственная безопасность и профессиональный риск // LAPISBN:978-3-659-25188-7

[5] Roland Iosif Moraru (2012). Current Trends and Future Developments in Occupational Health and Safety Risk Management, Risk Management for the Future - Theory and Cases, Dr Jan Emblemsvåg (Ed.), ISBN: 978-953-51-0571-8, InTech, Available from:

[6] Есбенбетова Ж.Х. (2018) Автомобиль көлігімен жүк тасымалдаушы кәсіпорын жұмыскерлерінің функционалдық жай-күйін еңбек жағдайларына байланысты бағалау // «Ғылымның өзекті мәселелері» - Халықаралық практикалық интернет- конференция материалдары/ Materials of International Practical Internet Conference "Challenges of Science". Басылым I, 2019. Бет: 276 - 281. https://doi.org/10.31643/2018.064

[7] Методические рекомендации по внедрению системы управления профессиональными рисками на предприятии // Бисакаев С.Г., Абикенова Ш.К., Есбенбетова Ж.Х.//SSBN 978-601-06-4724-4, - Астана: РГКП «РНИИОТ МТСЗН РК», Астана, 2017 г. 84 с. 